\title{
Ameliorative Effect of Quercetin on Methotrexate Induced Toxicity in Sprague-Dawley Rats: A Histopathological Study
}

\author{
Alexander Victor Anand David', Namani Satyanarayana', Subramani Parasuraman², \\ Sengodan Bharathi ${ }^{3}$, Radhakrishnan Arulmoli ${ }^{1}$
}

${ }^{1}$ Unit of Anatomy, Faculty of Medicine, AIMST University, Bedong-08100, MALAYSIA.

${ }^{2}$ Unit of Pharmacology, Faculty of Pharmacy, AIMST University, Bedong-08100, MALAYSIA.

${ }^{3}$ Unit of Pathology, Faculty of Medicine, AIMST University, Bedong-08100, MALAYSIA.

\begin{abstract}
Objective: To study the effect of quercetin on methotrexate induced toxicity and to observe the histopathological changes. Materials and Methods: Thirty male rats were divided into 5 different groups with each group consisting of six rats. The Group I was a control and they were treated with $10 \mathrm{ml} / \mathrm{kg}$ of carboxymethyl cellulose. The Group II, III, IV and V animals were treated with methotrexate $0.125 \mathrm{mg} / \mathrm{kg}$; methotrexate $0.25 \mathrm{mg} / \mathrm{kg}$; methotrexate $(0.125 \mathrm{mg} / \mathrm{kg})+$ quercetin $(500 \mathrm{mg} / \mathrm{kg})$; and methotrexate $(0.25 \mathrm{mg} / \mathrm{kg})+$ quercetin $(500 \mathrm{mg} / \mathrm{kg})$, respectively. All drugs were administered orally through oral gavage once daily for 14 days. At the end of the study, blood samples were collected from all the animals in each group. The animals were then sacrificed and organs were collected for histopathological analysis. Results: Methotrexate 0.125 and $0.25 \mathrm{mg} / \mathrm{kg}$ significantly increased the levels of liver enzymes such as AST, ALT, ALP and total protein and renal markers such as urea and creatinine. The animals treated with quercetin along with methotrexate showed significant improvement on methotrexate induced liver and renal toxicities. Methotrexate significantly reduced the levels of haemoglobin and blood sugar and which was partially reversed by quercetin. The notable histopathological changes in lungs, liver and kidneys were observed with methotrexate treated animals and this was protected by quercetin. Conclusion: Methotrexate produced significant pathological changes at $0.250 \mathrm{mg} / \mathrm{kg}$ and possible ameliorative effect of quercetin observed in lung, liver and kidney. Quercetin $500 \mathrm{mg} / \mathrm{kg}$ significantly inhibited the methotrexate induced toxicity in liver and kidneys.
\end{abstract}

Keywords: Antioxidants, Cytotoxicity, Histopathology, Methotrexate, Quercetin.

\section{INTRODUCTION}

Methotrexate is one of the folic acid antagonists which have been in use for decades as cancer chemotherapeutic agent and also used for the treatment of autoimmune diseases, inflammatory disorders and arthritis. ${ }^{1}$ In addition to its enlarged spectrum of clinical use, a well-defined toxicity profile has been identified and has a growing body of evidence which suggest significant toxic effect associated with its dose and duration. Methotrexate may cause mild to severe life threatening side effects which may cause reversible or irreversible adverse effect to the host. In variable dose, methotrexate produced renal and hepatic toxicities in animals. The low dosage methotrexate affects the liver and kidney functions causing changes in histological pattern of rats visceral organs. ${ }^{2,3}$

Methotrexate as far as possible should be considered only in the event of a life threatening neoplastic diseases and
Submission Date : 30-06-2015 Revision Date : :29-02-2016 Accepted Date : :08-03-2016

DOI: 10.5530/ijper.50.3.30 Correspondence:

Dr. Alexander Victor Anand David,

Unit of Anatomy, Faculty of Medicine, AIMST University, Bedong -08100

MALAYSIA.

E-mail: dr.vdavid7@gmail. com

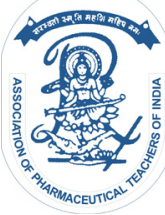

www.ijper.org 
in patients with severe recalcitrant disabling disease of psoriasis or rheumatoid arthritis. ${ }^{4}$ The effect concomitant administration of methotrexate and antioxidant remains unclear. Antioxidants are substances that interact with and neutralize or block free radicals thus preventing them from causing organ damage. Quercetin is known for its principal main feature as an antioxidant via direct free radical scavenging action and enhancing cyclic-GMP-dependent relaxation. ${ }^{5,6}$ It has been the most powerful dietary flavonoid for defending the body against reactive oxygen species. Quercetin is found in fruits (mainly citrus), green leafy vegetables, buckwheat, nuts, flowers, barks, broccoli, olive oil, apples, onions, green tea, red grapes, red wine, dark cherries and berries such as blue berries and cranberries. ${ }^{7}$ Quercetin appears to have many beneficial effects which include cardiovascular protection, antitumor, antiulcer, antiallergy, antiviral, prevents neurodegenerative disorders, anti-inflammatory activity, prevents diabetic neuropathy, gastro protective effects, antihypertensive, immunity and anti-infective effects. ${ }^{8-10}$ Effect of quercetin as a food supplement on methotrexate induced toxicity remains unclear. Hence the present study was planned to study an ameliorative effect of quercetin on methotrexate induced toxicity in Sprague-Dawley rats.

\section{MATERIALS AND METHODS}

\section{Animals}

Healthy adult male Sprague-Dawley (SD) rats, weighing 150-180 $\mathrm{g}$ were used for the experiment and they were obtained from Central Animal House, AIMST University, Malaysia. The animals were housed in Wi-Fi-free zone, large, spacious poly acrylic cages at an ambient room temperature with 12-h-light/12-h-dark cycle. The animals were fed with water, and normal rats pellet diet ad libitum. The study was approved by AIMST University Human and Animal Ethics Committee (AUHAEC8/ FOM/2014) and the study was conducted according to Animal Research Review Panel guidelines.

\section{Chemicals}

Methotrexate was purchased from Apex Pharmacy Marketing Sdn. Bhd. Malaysia, supplied as tablets in a dose of $2.5 \mathrm{mg} /$ tablet. Quercetin was purchased from Nacalai Tesque Inc., Japan. Renal and liver profile analytic strips (REFLOTRON) glucose strips manufactured by Roche Germany, purchased from Roche Diagnostic (M) Sdn. Bhd. Petaling Jaya, Selangor. Total Protein Biochemistry test kit, liquid base $125 \mathrm{ml} /$ kit manufactured from Cypress, Belgium purchased from Integrasi Sains Sdn. Bhd. Amanputra, Puchong, Selangor.

\section{Experimental Design}

Thirty adult male healthy SD rats were randomly divided into 5 different groups each group of 6 rats as follows:

Group I : Normal control (Carboxymethyl cellulose $10 \mathrm{ml} / \mathrm{kg}$ )

Group II : Methotrexate $0.125 \mathrm{mg} / \mathrm{kg}$

Group III : Methotrexate $0.25 \mathrm{mg} / \mathrm{kg}$

Group IV : Methotrexate $0.125 \mathrm{mg} / \mathrm{kg}+$ Quercetin $500 \mathrm{mg} / \mathrm{kg}$

Group V : Methotrexate $0.25 \mathrm{mg} / \mathrm{kg}+$ Quercetin $500 \mathrm{mg} / \mathrm{kg}$

The dose of methotrexate and quercetin were selected from previously published reprots. ${ }^{11-13}$ Methotrexate and quercetin were suspended in $0.5 \% \mathrm{~W} / \mathrm{V}$ carboxymethyl cellulose (CMC) and administered once daily through oral gavage for 14 days. The drugs were administered in the morning between 9:00 am to 10:00 am. Throughout the experiment period, body weights variations and behavioural alterations were monitored. At the end of the study, blood sample was collected from all the animals through retro-orbital plexus (for biochemical and haematological analysis) and they were sacrificed by cervical dislocation. Organs such as brain, lungs, heart, liver, kidney, spleen, skeletal muscle, stomach, jejunum and ileum were collected and preserved in 10\% formalin for histopathological analysis.

\section{Biochemical analysis}

One $\mathrm{ml}$ of blood sample was collected from all the experimental animals in a disodium EDTA tubes through retro-orbital plexus. ${ }^{14}$ The samples were centrifuged at $3000 \mathrm{rpm}$ for $20 \mathrm{~min}$. The plasma was separated and immediately processed for biochemical estimations. The plasma sample was subjected to analysis of biochemical parameters such as aspartate aminotransferase (AST), alanine aminotransferase (ALT), alkaline phosphatase (ALP), blood urea, serum creatinine, total protein, random blood glucose and haemoglobin estimation using commercial biochemical kits and REFLOTRON 'PLUS machine by Roche, USA.

\section{Histopathological analysis}

Part of the brain, lungs, heart, liver, kidney, spleen, skeletal muscle, stomach, jejunum and ileum were excised quickly and samples were preserved and fixed in 10\% neutral formalin for histopathological analysis. The sample tissues were embedded in paraffin blocks after being dehydrated in alcohol and subsequently cleared with xylene. Five to ten micrometre thickness of all the above mentioned tissue section were prepared from paraffin blocks placed on a glass slide and stained with haematoxylin and eosin. It is then mounted in neutral 
DPX medium and the slides were examined under light microscope. ${ }^{15,16}$

\section{Statistical analysis}

All the values are presented as mean \pm SEM (Standard estimated mean). The continuous variables of more than two groups analysed using one way analysis of variance (ANOVA) or repeated measure ANOVA followed by Bonferroni post hoc test. A $\mathrm{p}<0.05$ was considered as statistically significant.

\section{RESULTS}

Quercetin $500 \mathrm{mg} / \mathrm{kg}$ administered animals showed significant protective effect on methotrexate induced respiratory, hepatic and renal toxicity. Methotrexate treated animals showed clinical signs like dullness, lethargy, and loss of appetite with decrease in food consumption leading to reduction in the body weight possibly due to methotrexate toxicity (Table 1).

The animals treated with methotrexate 0.125 and $0.25 \mathrm{mg} / \mathrm{kg}$ showed significant loss of body weight in first week onwards and they have incidence of abnormal bowel clearance with diarrhoea and increased urine excretion. They also showed significant increase in levels of AST, ALT, ALP and total protein when compared with control (Table 2). Whereas animals treated with quercetin showed significant protective effect on methotrexate elevated liver enzymes. When compared with control, significant increased levels of creatinine and blood urea was observed in methotrexate treated groups and this may indicate that the reduction in renal filtration rate can be due to toxic effects of methotrexate on kidney (Table 2). Methotrexate along with quercetin treated animals also showed significant increase in the levels of creatinine when compared with control. Methotrexate and methotrexate along with quercetin showed significant increase in the levels of random blood sugar and haemoglobin when compared with that of control (Table 3).

The animals treated with drug vehicle did not showed any significant changes in histological features of cerebrum, cardiac muscle, lungs, liver, kidneys, spleen, skeletal muscle, stomach, jejunum and ileum. Whereas the animals treated with methotrexate 0.125 and 0.25 $\mathrm{mg} / \mathrm{kg}$ showed significant changes in histological features of lungs, liver and kidney.

Methotrexate $0.125 \mathrm{mg} / \mathrm{kg}$ showed alterations such as sinusoidal dilation and mild congestion of liver parenchyma; moderate interstitial congestion in kidney; congested septal capillaries, numerous inflammatory infiltrate and abnormally large alveoli in lungs (Figure 1, 2, 3). Histo- pathological lesions of lungs with methotrexate 0.125 $\mathrm{mg} / \mathrm{kg}$ treated animals showed congested septal capillaries, numerous inflammatory infiltrate and abnormal large alveoli. The abnormally large alveoli are separated by thin septa with mild vascular congestion present. Animals treated with methotrexate $0.25 \mathrm{mg} / \mathrm{kg}$ showed sinusoidal dilation with severe congestion in liver parenchyma; extensive interstitial congestion in kidney; revealed congested septal capillaries, numerous intense inflammatory infiltrate and abnormally large alveoli noted with vascular congestion in lungs (Figure 4, 5, 6). Animals treated with methotrexate $0.125 \mathrm{mg} / \mathrm{kg}$ along with quercetin $500 \mathrm{mg} / \mathrm{kg}$ showed less congestion in liver; mild interstitial congestion in kidney; no morphological changes in normal structure of lungs (Figure 7, $8,9)$. Animals treated with methotrexate $0.25 \mathrm{mg} / \mathrm{kg}$ along with quercetin $500 \mathrm{mg} / \mathrm{kg}$ showed no morphological changes in liver and lungs and mild interstitial congestion in kidneys (Figure 10, 11, 12). The histopathological analysis of methotrexate administered animals showed dose dependent morphological changes in the lung, liver and kidney.

\section{DISCUSSION}

Methotrexate is a folate antagonist inhibiting the proliferation of malignant cells by inhibition of dihydrofolatereductase enzyme. It is an antitumor agent mainly used for the treatment of childhood acute lymphoblastic leukemia (ALL) and also used as a disease modifying agent for the treatment of rheumatoid arthritis. ${ }^{17,18}$ Methotrexate exhibits nephrotoxicity, hepatotoxicity, and toxicity to the respiratory and reproductive system at a very low dose. It is widely distributed into body tissues with highest concentrations in the kidney, spleen, liver and skin. It is retained in the form of polyglutamates for several weeks in the kidneys and for months in the liver ${ }^{19} \mathrm{We}$ also found that high dose of methotrexate resulted in diarrhea with increased consumption of water. This is in accordance to a study done which revealed methotrexate causes changes in the bowel motility whereby the possible reason for this could be corrosive and irritating effects of methotrexate on gastrointestinal mucosa. ${ }^{19,20}$ In addition to gastrointestinal toxicity, weight loss observed in methotrexate treated animals may be a due to direct toxicity, reduced feed and water intake which are in agreement with previous studies. ${ }^{21}$

In the present study, increased level of AST, ALT, ALP were observed in methotrexate treated animals which indicates possible damage caused by methotrexate toxicity to the liver. Methotrexate induced hepatotox- 
Table 1: Effect of methotrexate and methotrexate+quercetin on body weight of the rats

\begin{tabular}{|c|c|c|c|}
\hline Group & Pre-study & Week 1 & Week 2 \\
\hline Normal control & $160.00 \pm 2.63$ & $168.33 \pm 4.01$ & $171.67 \pm 6.54$ \\
\hline Methotrexate $0.125 \mathrm{mg} / \mathrm{kg}$ & $163.33 \pm 2.11$ & $161.67 \pm 1.67$ & $170.00 \pm 3.65$ \\
\hline Methotrexate $0.25 \mathrm{mg} / \mathrm{kg}$ & $170.00 \pm 3.65$ & $163.33 \pm 3.33$ & $158.50 \pm 0.81^{\mathrm{a}}$ \\
\hline Methotrexate $0.125 \mathrm{mg} / \mathrm{kg}+$ Quercetin $500 \mathrm{mg} / \mathrm{kg}$ & $150.00 \pm 6.32$ & $171.67 \pm 6.01$ & $158.33 \pm 6.54$ \\
\hline Methotrexate $0.25 \mathrm{mg} / \mathrm{kg}+$ Quercetin $500 \mathrm{mg} / \mathrm{kg}$ & $171.67 \pm 4.01$ & $182.00 \pm 1.63$ & $176.67 \pm 2.87$ \\
\hline
\end{tabular}

All the values are mean \pm SEM of six rats $(n=6) .{ }^{a} p<0.05$ when compared to the pre-study body weight. (One-way ANOVA followed by bonferroni post hoc test).

\begin{tabular}{|c|c|c|c|c|c|c|}
\hline \multicolumn{6}{|c|}{ Table 2: Effect of methotrexate and methotrexate+quercetin on biochemical parameter } \\
\hline Group & AST (IU/L) & ALT (IU/L) & ALP (IU/L) & TP (g/dL) & $\begin{array}{c}\text { Urea (mg/dL) } \\
\text { Creatinine } \\
(\mathbf{m g} / \mathrm{dL})\end{array}$ \\
\hline Normal control & $120.02 \pm 0.71$ & $42.61 \pm 0.82$ & $164.94 \pm 0.18$ & $7.35 \pm 0.02$ & $17.17 \pm 0.30$ & $0.46 \pm 0.01$ \\
\hline Methotrexate $0.125 \mathrm{mg} / \mathrm{kg}$ & $155.84 \pm 1.70^{\mathrm{c}}$ & $46.43 \pm 0.27^{\mathrm{c}}$ & $167.43 \pm 0.23$ & $6.93 \pm 0.02^{\mathrm{a}}$ & $18.30 \pm 0.32^{\mathrm{c}}$ & $0.49 \pm 0.01^{\mathrm{c}}$ \\
\hline Methotrexate $0.25 \mathrm{mg} / \mathrm{kg}$ & $173.23 \pm 1.62^{\mathrm{c}}$ & $49.81 \pm 0.48^{\mathrm{c}}$ & $196.44 \pm 0.50^{\mathrm{c}}$ & $5.63 \pm 0.05^{\mathrm{c}}$ & $17.85 \pm 0.30^{\mathrm{a}}$ & $0.57 \pm 0.01^{\mathrm{c}}$ \\
\hline $\begin{array}{c}\text { Methotrexate } 0.125 \mathrm{mg} / \mathrm{kg}+ \\
\text { Quercetin } 500 \mathrm{mg} / \mathrm{kg}\end{array}$ & $158.34 \pm 3.96^{\mathrm{c}}$ & $40.80 \pm 1.21^{\mathrm{a}}$ & $164.24 \pm 0.55$ & $6.07 \pm 0.55^{\mathrm{c}}$ & $16.93 \pm 0.40$ & $0.49 \pm 0.02^{\mathrm{c}}$ \\
\hline $\begin{array}{c}\text { Methotrexate } 0.25 \mathrm{mg} / \mathrm{kg}+ \\
\text { Quercetin } 500 \mathrm{mg} / \mathrm{kg}\end{array}$ & $150.07 \pm 6.88^{\mathrm{c}}$ & $42.51 \pm 0.79$ & $169.63 \pm 3.94^{\mathrm{b}}$ & $6.26 \pm 0.29^{\mathrm{c}}$ & $17.12 \pm 0.30$ & $0.53 \pm 0.03^{\mathrm{c}}$ \\
\hline
\end{tabular}

All the values are mean \pm SEM of six rats $(n=6)$. ${ }^{a} p<0.05 ;{ }^{b} p<0.01$ and ${ }^{c} p<0.001$ compared to the pre-study body weight. (One-way ANOVA followed by bonferroni post hoc test). AST: Aspartate aminotransferase, ALT: Alanine aminotransferase, ALP: Alkaline phosphatase, TP: Total protein.

\begin{tabular}{|c|c|c|}
$\begin{array}{c}\text { Table 3: Effect of methotrexate and methotrexate + quercetin on blood } \\
\text { sugar and haemoglobinparameters }\end{array}$ \\
\hline Group & RBS (mmol/dl) & Hb (g/dL) \\
\hline Normal control & $4.15 \pm 0.28$ & $13.07 \pm 0.12$ \\
\hline Methotrexate $0.125 \mathrm{mg} / \mathrm{kg}$ & $3.92 \pm 0.15^{\mathrm{c}}$ & $11.98 \pm 0.07^{\mathrm{c}}$ \\
\hline Methotrexate $0.25 \mathrm{mg} / \mathrm{kg}$ & $3.97 \pm 0.22^{\mathrm{c}}$ & $10.70 \pm 0.32^{\mathrm{c}}$ \\
\hline Methotrexate $0.125 \mathrm{mg} / \mathrm{kg}+$ Quercetin $500 \mathrm{mg} / \mathrm{kg}$ & $4.73 \pm 0.16^{\mathrm{c}}$ & $12.10 \pm 0.09^{\mathrm{c}}$ \\
\hline Methotrexate $0.25 \mathrm{mg} / \mathrm{kg}+$ Quercetin $500 \mathrm{mg} / \mathrm{kg}$ & $4.18 \pm 0.14^{\mathrm{c}}$ & $11.38 \pm 0.23^{\mathrm{c}}$ \\
\hline
\end{tabular}

RBS:Random Blood Sugar; HB: Haemoglobin. All the values are mean \pm SEM of six rats $(n=6) \cdot{ }^{c} p<0.001$ compared to the pre-study body weight. One-way ANOVA followed by bonferroni post hoc test.
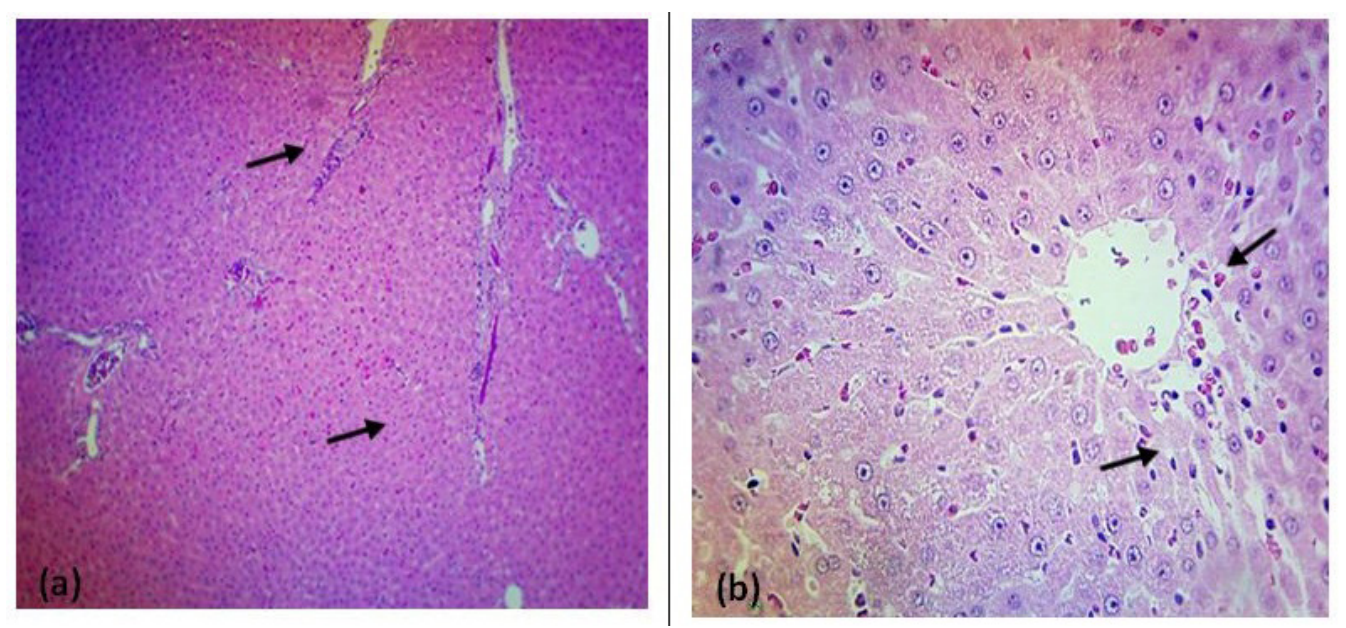

Figure 1: Photomicrograph of a section from liver (Group II Low dose MTX) with mild congestion (arrow), no inflammatory cell infiltrate or necrosis is noted. The hepatocytes appear normal no swelling or degeneration seen. (a) H\&E, 10X (b) H\&E,40X. 

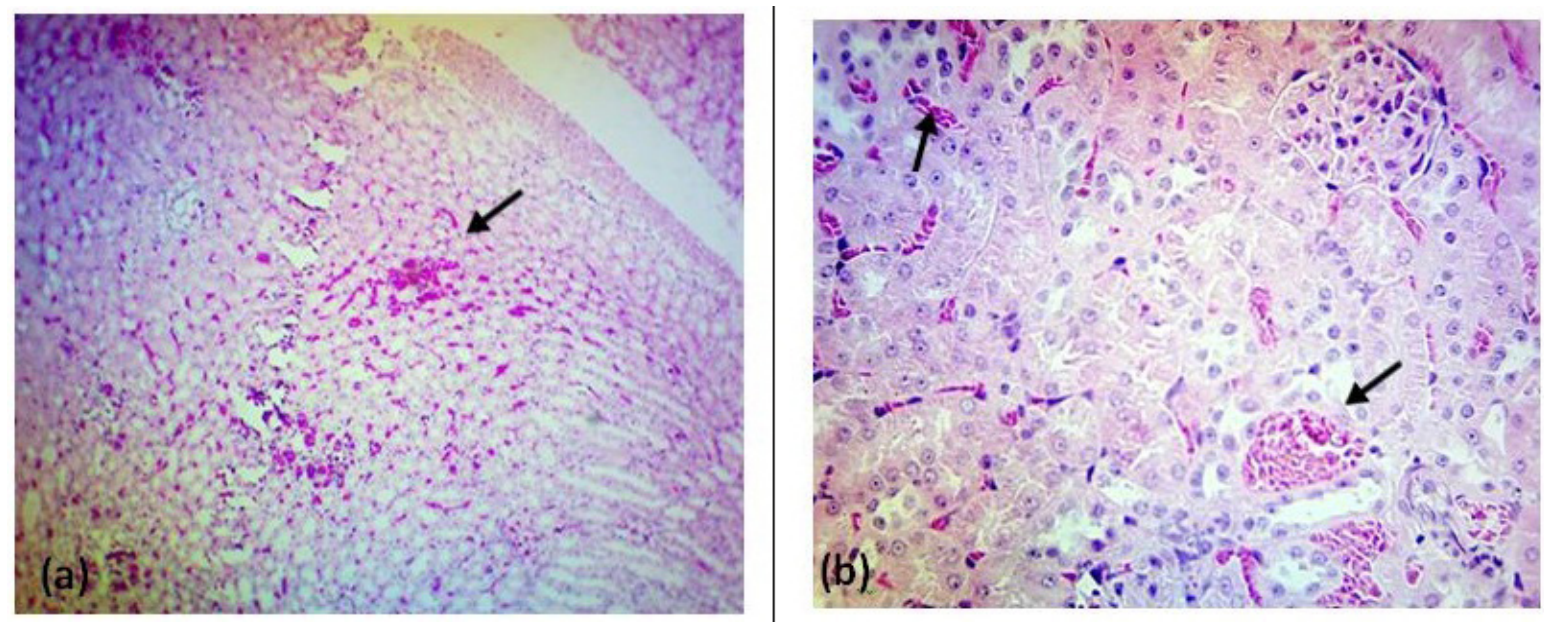

Figure 2: Photomicrograph of a section from kidney (Group II - low dose MTX) showing normal tubular epithelial cells, no necrosis noted. There is moderate interstitial congestion (arrow), no inflammatory infiltrate seen.(a) H\&E,10X (b) H\&E,40X.
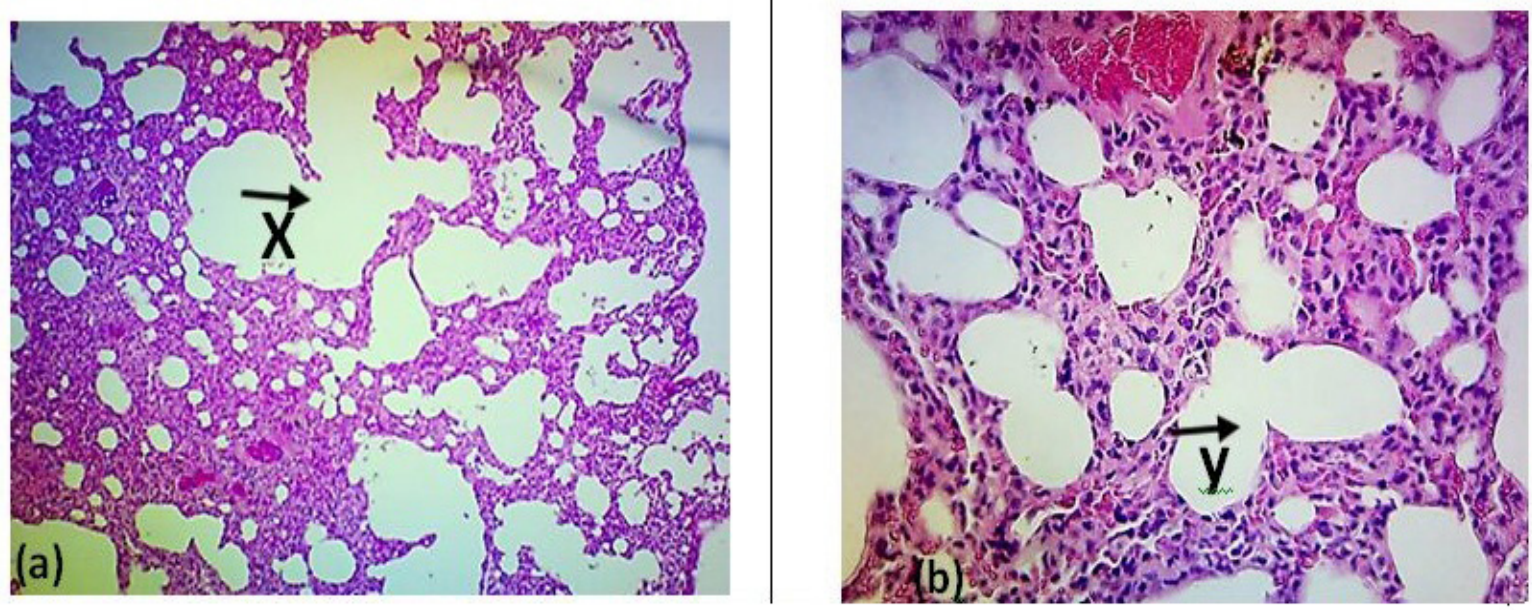

Figure 3: Photomicrograph of a section from lung (Group II-Low dose MTX) shows congested septal capillaries and numerous inflammatory infiltrate (arrow x), no intra-alveolar exudate seen. Abnormal large alveoli (arrow y) are separated by thin septa are also noted, mild vascular congestion present. (a) H\&E,10X (b) H\&E,40X.
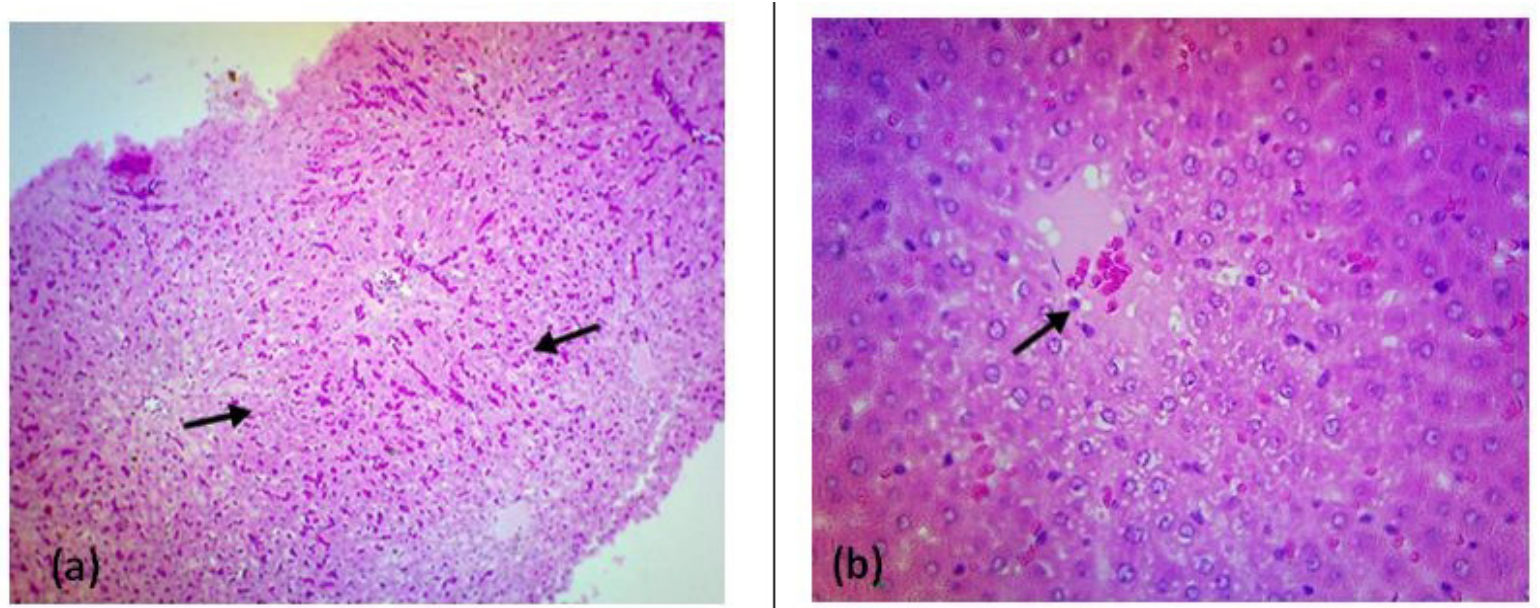

Figure 4: Photomicrograph of a section from liver (Group III High dose MTX) with sinusoidal dilation and severe congestion (arrow), no inflammatory cell infiltrate or necrosis is noted. The hepatocytes appear normal no swelling or degeneration seen. (a) $H \& E, 10 X(b) H \& E, 40 X$. 

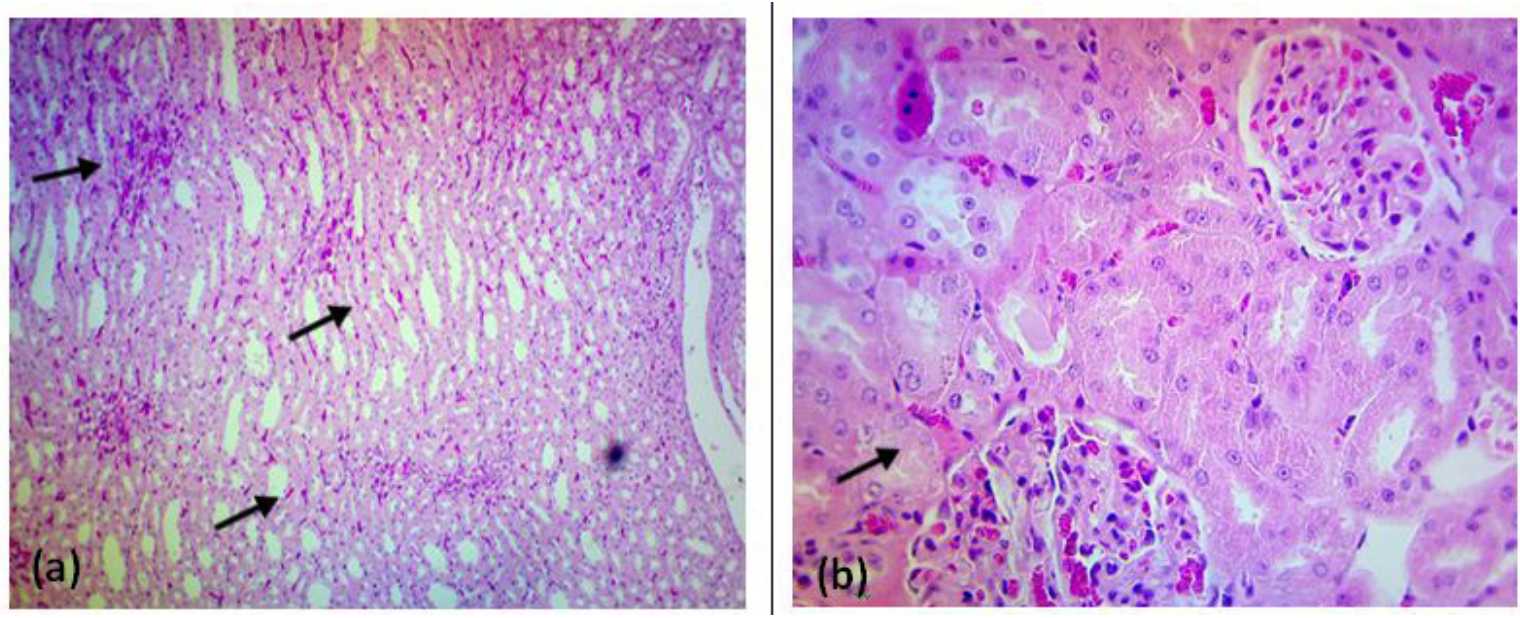

Figure 5: Photomicrograph of a section from kidney (Group III - high dose MTX) showing normal tubular epithelial cell, no necrosis noted. There is extensive interstitial congestion (arrow). no inflammatory infiltrate seen. (a) H\&E,10X (b) H\&E,40X.
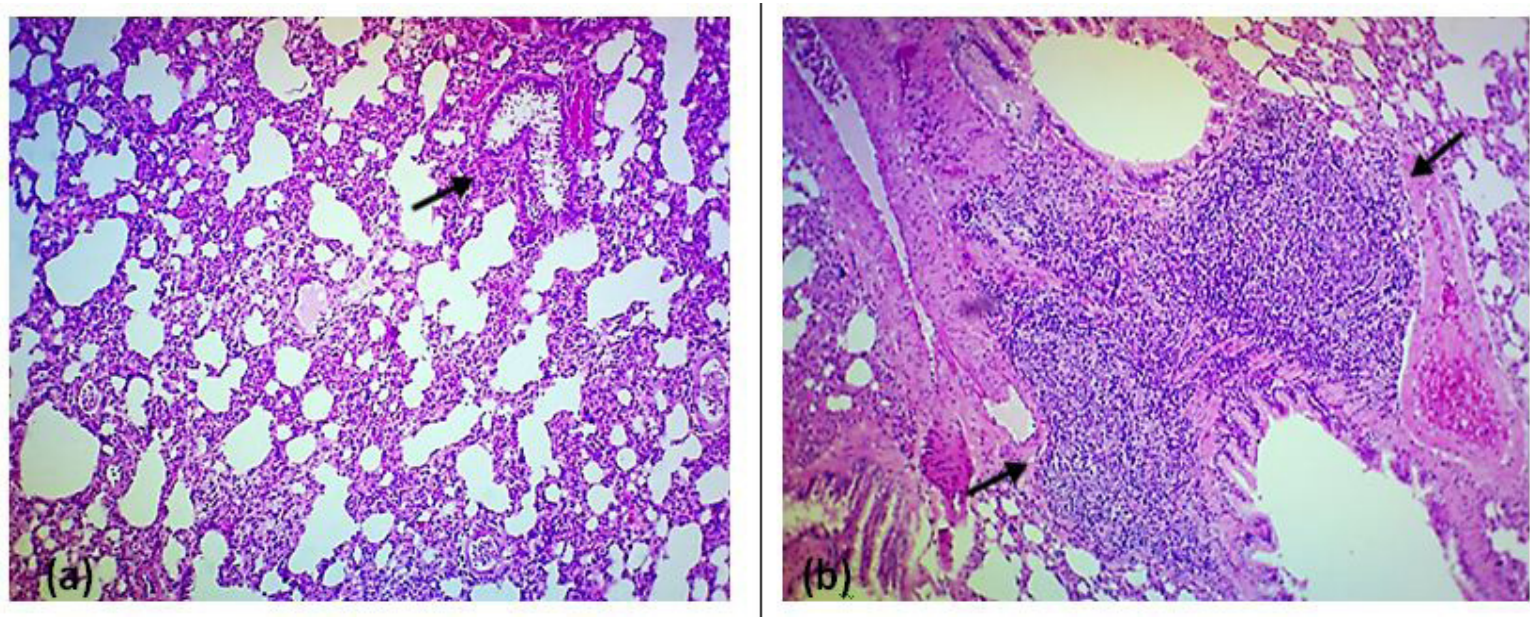

Figure 6: Photomicrograph of a section from lung (Group III High dose MTX) this area of the lung show intense inflammatory infiltrate forming lymphoid aggregates (arrow). (a) H\&E,10X (b) H\&E,40X.
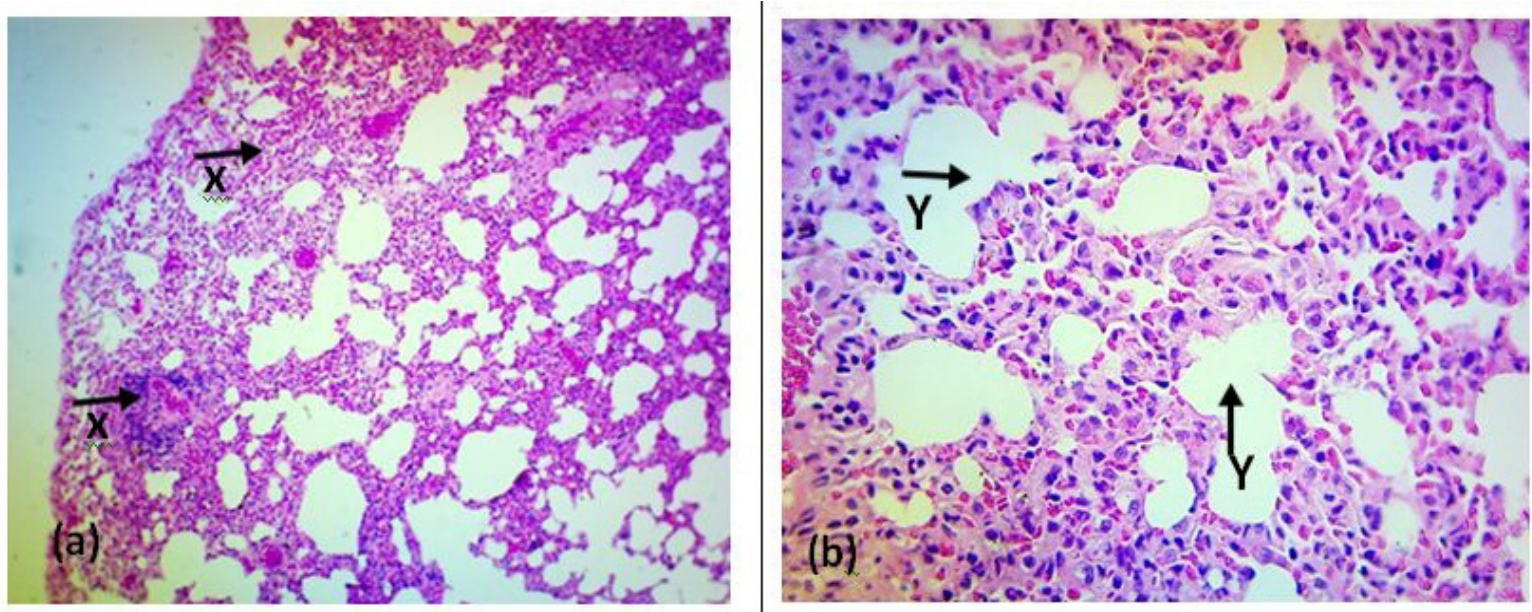

Figure 7: Photomicrograph of a section from lung (Group IV-Low dose MTX + Quercetin) shows congested septal capillaries and moderate inflammatory infiltrate with one area of perivascular dense inflammation (arrow $x$ ), no intra-alveolar exudate seen. Fused large alveoli are noted (arrow y). Vascular congestion present (a) H\&E,10X (b) H\&E,40X. 

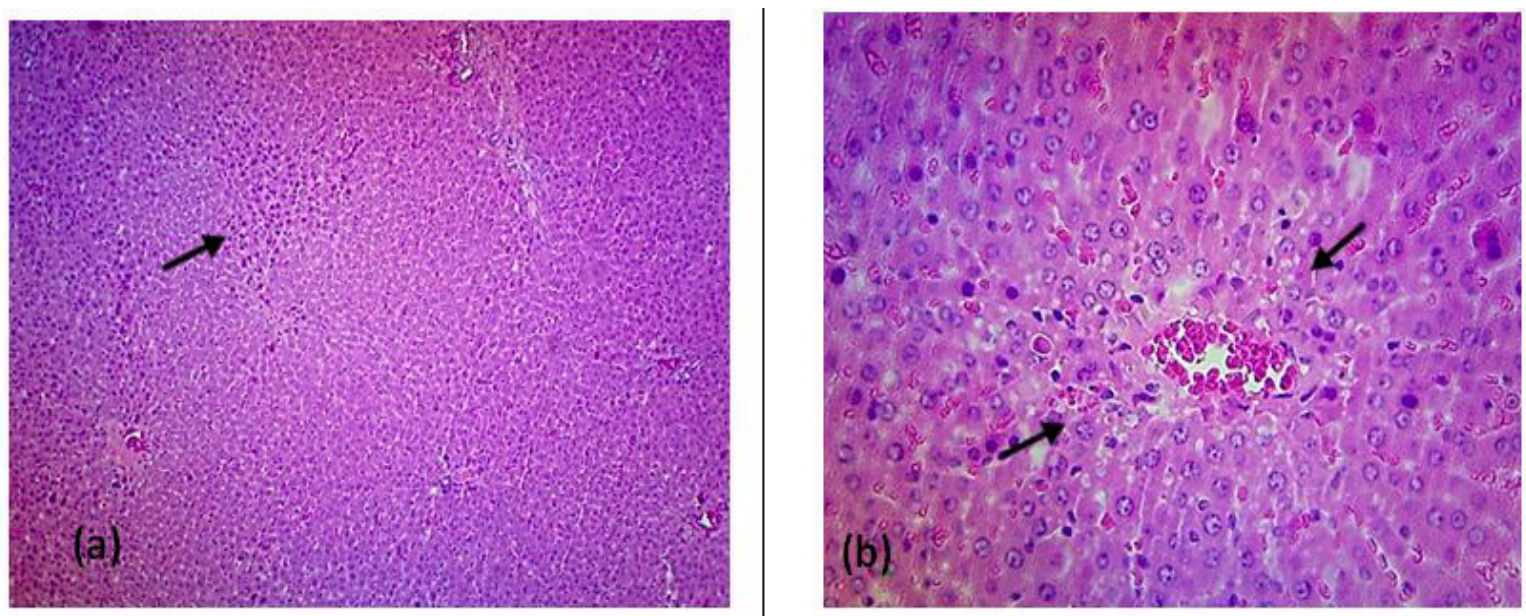

Figure 8: Photomicrograph of a section from liver (Group IV Low dose MTX + Quercetin) with mild congested sinusoids (arrow), no inflammatory cell infiltrate or necrosis is noted. The hepatocytes appear normal no swelling or degeneration seen. (a) H\&E,10X (b)H\&E,40X.
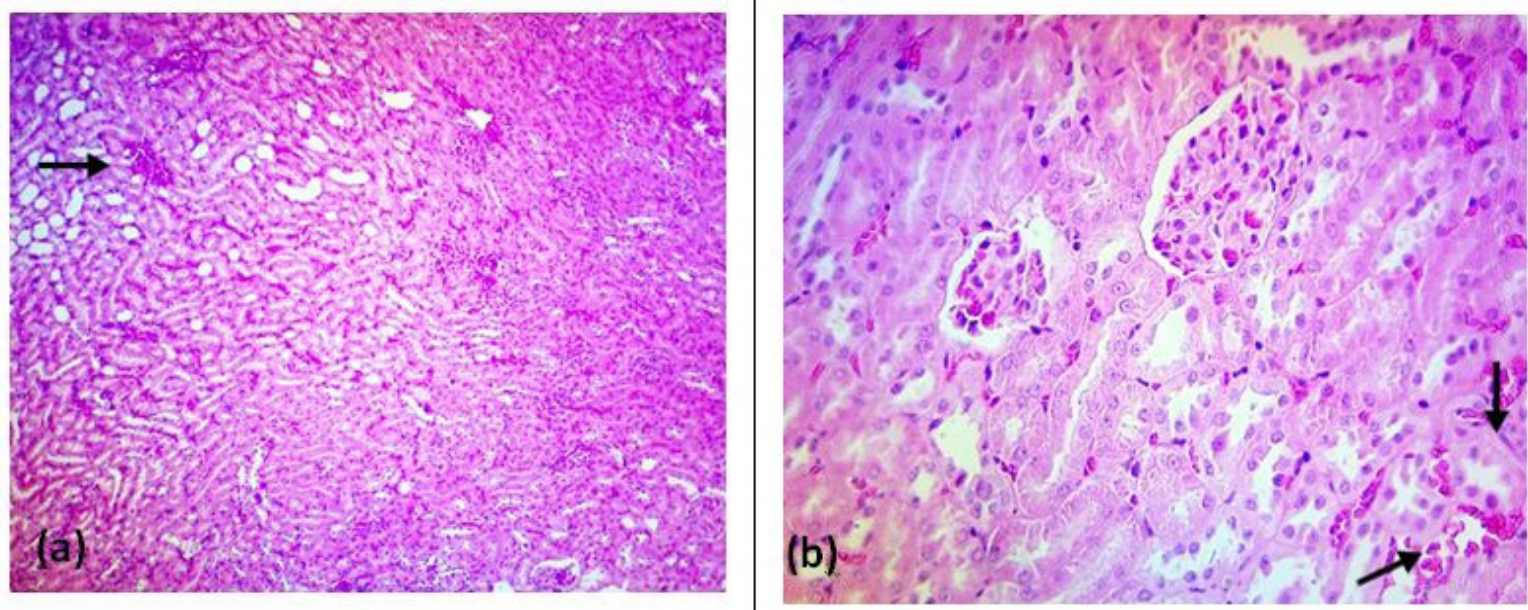

Figure 9: Photomicrograph of a section from kidney (Group IV - low dose MTX + Quercetin) showing normal tubular epithelial cells, no necrosis noted. There are few areas of interstitial congestion (arrow). No inflammatory infiltrate seen. (a) H\&E,10X (b) $H \& E, 40 X$.
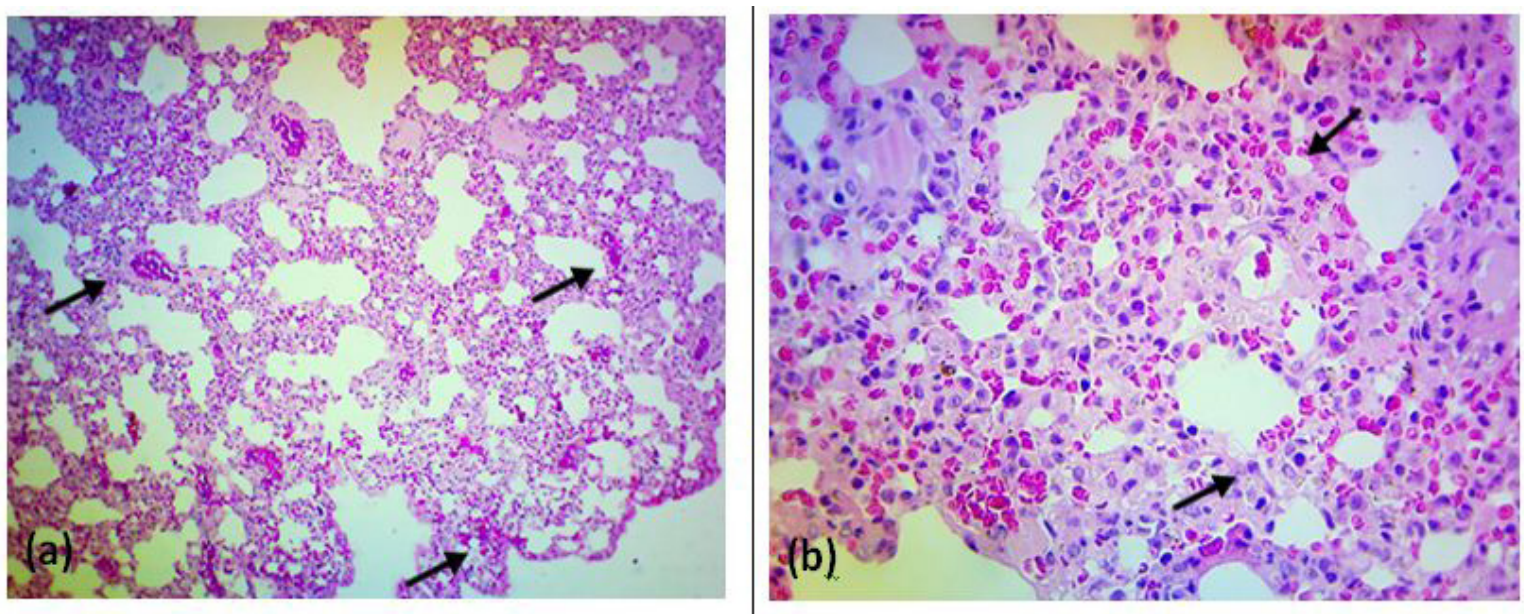

Figure 10: Photomicrograph of a section from lung (Group V High dose MTX + Quercetin)the lung has dilated congested septal capillaries and moderate inflammatory infiltrate (arrow). No intra-alveolar exudate seen.Fused large alveoli are noted. Vascular congestion was present. (a) H\&E,10X (b) H\&E,40X. 

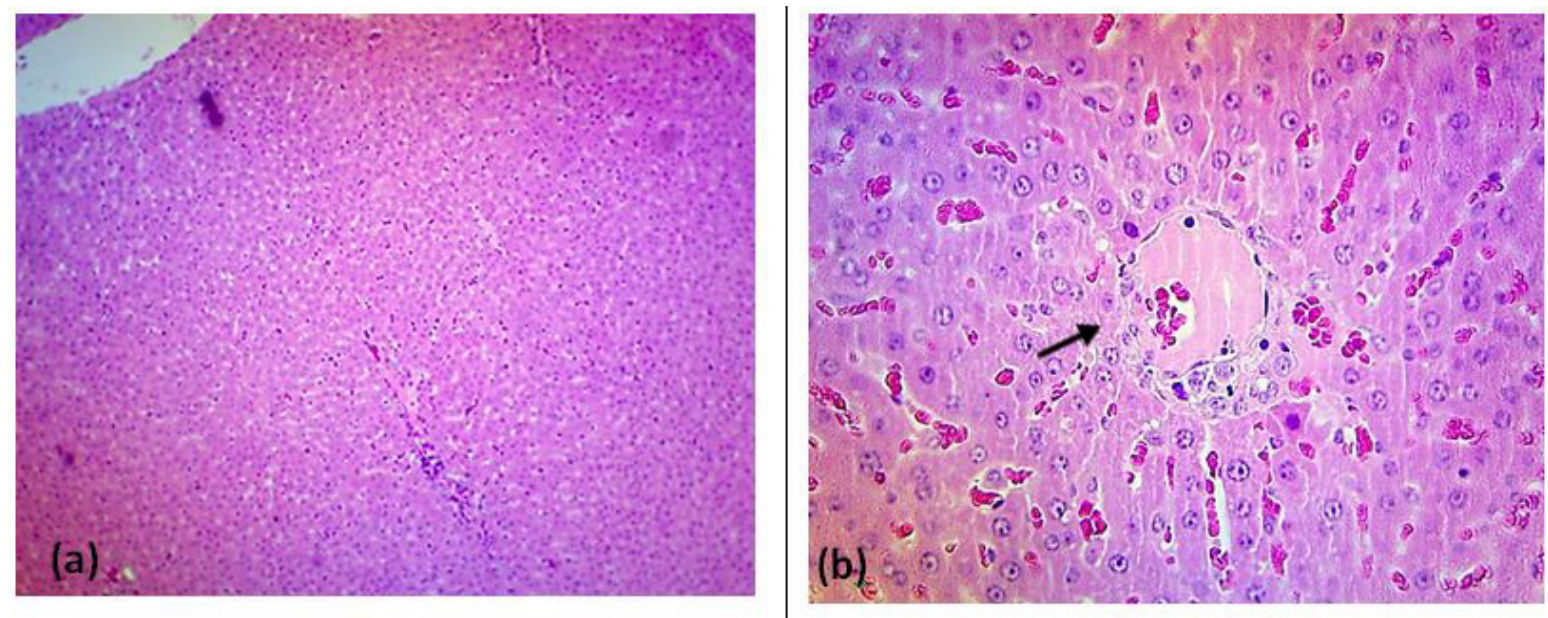

Figure 11: Photomicrograph of a section from liver (Group V High dose MTX + Quercetin) with no sinusoidal dilation and very less congestion, No inflammatory cell infiltrate or necrosis is noted. The hepatocytes appear normal no swelling or degeneration seen. (a) H\&E, 10X (b) H\&E,40X.
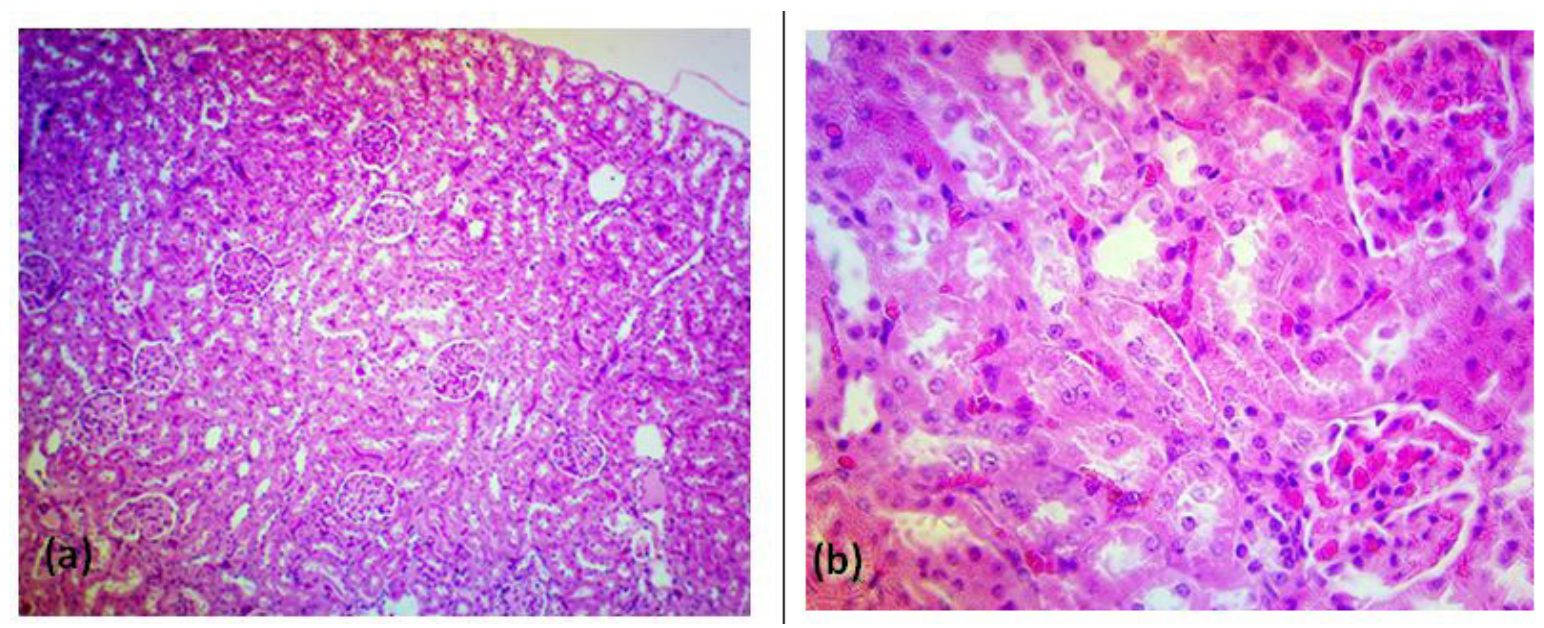

Figure 12: Photomicrograph of a section from Kidney (Group V-high dose MTX + Quercetin) showing normal architecture with normal appearing glomeruli and tubules. (a) H\&E,10X (b) H\&E,40X.

icity is well-known and single dose of methotrexate is enough to induce liver enzyme impairment which includes elevation of ALT levels. ${ }^{22}$ Renal markers such as creatinine and urea were also seen to be elevated in methotrexate treated animals indicating possible nephrotoxicity. The significant changes in these biochemical parameters are due to the effect of methotrexate on morphology and function of liver and kidney.The mechanism involved in hepatorenal damage caused by methotrexate is remains unclear. El-Sheikh et al., found imparted levels of oxidative stress parameters, nitroxidative stress and downregulation of TNF- $\alpha$ / $\mathrm{NF}-x \mathrm{~B} / \mathrm{COX}-2$ inflammatory pathway in methotrexate treated animals and this may contribute in the development of hepatorenal damage. ${ }^{23} \mathrm{Kalemci}$ et al., also found that increase in liver enzyme levels and increased rate of inflammatory cell infiltration in pulmonary tissue of methotrexate treatment rats. The increased rate of inflammatory cell infiltration in pulmonary tissue may be due to mitogen-activated protein kinase (MAPK) and Akt pathways. ${ }^{24}$

Quercetin, an antioxidant flavonoid widely distributed in plants, green leafy vegetables and fruits has shown beneficial effects in various diseases. The dissemination of quercetin and its metabolites in rats are well distributed in tissues whereby highest concentration noted in lungs and lowest in brain and spleen. ${ }^{25} \mathrm{We}$ observed that quercetin prevented the methotrexate induced hepatorenal toxicity in rats. Aydin also reported the hepatoprotective effect of quercetin against methotrexate-induced hepatotoxicity in adult male Swiss albino mice by mitigate the effect on the induction of phase I enzymes by methotrexate without altering the outcome of methotrexate metabolism. ${ }^{26}$ The other possibility for hepatoprotective activity of quercetin is may be due to its free-radical scavenging properties, inhibiting $\mathrm{NF}-x \mathrm{~B}$ activation, inhibiting inflammatory 
response and exerting antifibrotic potential. ${ }^{27}$ Kahraman et al., also reported the renoprotective effect and free-radical scavenging properties of quercetin. ${ }^{28}$

\section{CONCLUSION}

This study leads to the conclusion that quercetin may have an ameliorative or protective effect on methotrexate induced respiratory, liver and renal toxicity.

\section{CONFLICT OF INTEREST}

The author have no conflict of interest to declare.

\section{ABBREVIATION USED}

ANOVA: Analysis of variance; ALL: Acute lymphoblastic leukemia; ALP: Alkaline phosphatase; ALT: Alanine aminotransferase; AST: Aspartate aminotransferase; CMC: Carboxymethyl cellulose; COX2: Cyclooxygenase 2; DPX: Distrene, Plasticiser, Xylene; EDTA: Ethylenediaminetetraacetic acid; GMP: Guanosine monophosphate; MAPK: Mitogen-activated protein kinase; SEM: Standard estimated mean; SD rats: Sprague Dawley rat; TNF: Tumor necrosis factor.

\section{REFERENCES}

1. Skubisz MM, Tong S. The evolution of methotrexate as treatment for ectopic pregnancy and gestational trophoblastic neoplasia: a review. ISRN Obstet Gynecol. 2012;2012:637094.

2. Murakami Y, Yamazaki K, Sakauchi N, Ogasawara H, Yamashita N, Masuda T, et al. A one-month repeated oral dose toxicity study of methotrexate in unilaterally nephrectomized rats. J Toxicol Sci. 1998;23Suppl 5:681-99. http://dx.doi.org/10.2131/jts.23.SupplementV_681; PMid:9891907.

3. Fan C, Georgiou KR, King TJ, Xian CJ. Methotrexate toxicity in growing long bones of young rats: a model for studying cancer chemotherapy-induced bone growth defects in children. J Biomed Biotechnol. 2011;2011:903097. http:// dx.doi.org/10.1155/2011/903097 ; PMid:21541196 PMCid:PMC3085506.

4. Chemistry and Toxicology devices Methotrexate Test System 2013. Executive summary. Available in www.fda.gov (Last accessed on 8th March 2015).

5. Suri S, Liu XH, Rayment S, Hughes DA, Kroon PA, Needs PW, et al. Quercetin and its major metabolites selectively modulate cyclic GMPdependent relaxations and associated tolerance in pig isolated coronary artery. Br J Pharmacol. 2010;159(3):566-75. http://dx.doi.org/10.1111/j.14765381.2009.00556.x; PMid:20050852 PMCid:PMC2828021.

6. Zhang M, Swarts SG, Yin L, Liu C, Tian Y, Cao Y, et al. Antioxidant properties of quercetin. Adv Exp Med Biol. 2011;701:283-9. http://dx.doi.org/10.1007/9781-4419-7756-4_38; PMid:21445799.

7. Sultana B, Anwar F. Flavonols (kaempeferol, quercetin, myricetin) contents of selected fruits, vegetables and medicinal plants. Food Chem. 2008;108(3):879-84. http://dx.doi.org/10.1016/j.foodchem.2007.11.053 ; PMid:26065748.

8. Gormaz JG, Quintremil S, Rodrigo R. Cardiovascular Disease: A Target for the Pharmacological Effects of Quercetin. Curr Top Med Chem. 2015;15(17):1735-42. http://dx.doi.org/10.2174/1568026615666150427124 357; PMid:25915608.

9. Boots AW, Haenen GR, Bast A. Health effects of quercetin: from antioxidant to nutraceutical. Eur J Pharmacol. 2008;585(2-3):325-37. http://dx.doi. org/10.1016/j.ejphar.2008.03.008; PMid:18417116.
10. Gibellini L, Pinti M, Nasi M, Montagna JP, De Biasi S, Roat E, et al. Quercetin and cancer chemoprevention. Evid Based Complement Alternat Med. 2011;2011:591356. http://dx.doi.org/10.1093/ecam/neq053 ; PMid:21792362 PMCid:PMC3136711.

11. Goldberg RL, Rubin AS. Serum hyaluronate as a marker for disease severity in the Lactobacillus casei model of arthritis in the rat. J Rheumatol. 1989;16(1):92-6. PMid:2497256.

12. Filho AW, Filho VC, Olinger L, de Souza MM. Quercetin: further investigation of its antinociceptive properties and mechanisms of action. Arch Pharm Res. 2008;31(6):713-21. http://dx.doi.org/10.1007/s12272-001-1217-2 ; PMid:18563352.

13. Hall PD, Jenner MA, Ahern MJ. Hepatotoxicity in a rat model caused by orally administered methotrexate. Hepatology. 1991;14(5):906-10. http://dx.doi. org/10.1002/hep.1840140525; PMid:1937394.

14. Parasuraman S, Zhen KM, Raveendran R. Retro-orbital Blood Sample Collection in Rats-a Video Article. PTB Rep. 2015;1(2):37-40. http://dx.doi. org/10.5530/PTB.1.2.1.

15. Parasuraman S, Raveendran R, Rajesh NG, NandhakumarS. Sub-chronic toxicological evaluation of cleistanthin $A$ and cleistanthin $B$ from the leaves of Cleistanthuscollinus (Roxb.) Toxicol Rep 2014;1:596-611. http://dx.doi. org/10.1016/j.toxrep.2014.08.006.

16. Umarani S, Sivaraj R, Parasuraman S, Gunasekaran JP. Effect of vasectomy on testis and epididymis in adult male Swiss albino mice: Histological and histometric study. Indian IJPER. 2014;48(2):55-64. http://dx.doi.org/10.5530/ ijper.48.2.8.

17. Patel NN, Ghodasara DJ, Pandey S, Ghodasara PD, Khorajiya JH, Joshi BH. Subacutetoxicopathological studies of methotrexate in Wistar rats. Vet World. 2014;7:489-95. http://dx.doi.org/10.14202/vetworld.2014.489-495.

18. Malik F, Ranganathan P. Methotrexate pharmacogenetics in rheumatoid arthritis: a status report. Pharmacogenomics. 2013;14:305-14. http://dx.doi. org/10.2217/pgs.12.214; PMid:23394392.

19. de Boer VCJ, Dihal AA, van-der-Woude H, Arts IC, Wolffram S, Alink GM, et al. Tissue distribution of quercetin in rats and pigs. J Nutr. 2005;135:1718-25. PMid:15987855

20. Perianayagasamy AM, Gomez PP, Dhasarathan P. Therapeutical effect of melatonin and glutamine against rats bone marrow toxicity induced by methotrexate. J Bio Sci Res. 2010;1:202-07.

21. Uraz S, Tahan V, Aygun C, Eren F, Unluguzel G, Yuksel M, et al. Role of ursodeoxycholi acid in prevention of methotrexate induced liver toxicity. Dig Dis Sci. 2008;53:1071-77. http://dx.doi.org/10.1007/s10620-007-9949-3 ; PMid:17934844.

22. Rogerio AP, Kanashiro A, Fontanari C, da Silva EV, Lucisano-Valim YM, Soares EG, et al. Anti-inflammatory activity of quercetin and isoquercitrin in experimental murine allergic asthma. Inflamm Res. 2007;56(10):402-8. http://dx.doi.org/10.1007/s00011-007-7005-6; PMid:18026696

23. El-Sheikh AA, Morsy MA, Abdalla AM, Hamouda AH, Alhaider IA. Mechanisms of Thymoquinone Hepatorenal Protection in MethotrexateInduced Toxicity in Rats. Mediators Inflamm. 2015;2015:859383. http:// dx.doi.org/10.1155/2015/859383; PMid:26089605 PMCid:PMC4455533.

24. Kalemci S, Topal Y, Celik SY, Yilmaz N, Beydilli H, Kosar MI, et al. Silibinin attenuates methotrexate-induced pulmonary injury by targeting oxidative stress. Exp Ther Med. 2015;10(2):503-7. http://dx.doi.org/10.3892/ etm.2015.2542

25. Anafi SB, Kwanashie HO, Anuka JA, Muktar HM, Agbaji AS. Changes in immunological and haematological parameters association with cyclophosphamide and methotrexate administration in wistar rats. Nig J Pharm Sci. 2013;12:1-8.

26. Aydin B. Quercetin prevents methotrexate-induced hepatotoxicity without interfering methotrexate metabolizing enzymes in liver of mice. Journal of Applied Biological Sciences. 2011;5(2):75-80.

27. Domitrović $R$, Jakovac $H$, Vasiljev Marchesi V, Vladimir-Knežević $S$, Cvijanović $\mathrm{O}$, et al. Differential hepatoprotective mechanisms of rutin and quercetin in $\mathrm{CCl}$ (4)-intoxicated $\mathrm{BALB} / \mathrm{CN}$ mice. Acta Pharmacol Sin. 2012;33(10):1260-70. http://dx.doi.org/10.1038/aps.2012.62; PMid:22902988 PMCid:PMC4002705

28. Kahraman A, Erkasap N, Serteser M, Köken T. Protective effect of quercetin on renal ischemia/reperfusion injury in rats. J Nephrol. 2003;16(2):219-24. PMid: 12768068 